\title{
Seismic Performance of Infilled Framed Structures with Open Ground Storey
}

\author{
[M. M. Abdelaziz ${ }^{1}$, M. S. Gomaa ${ }^{2}$, and H. El-Ghazaly ${ }^{3}$ ]
}

\begin{abstract}
Masonry Infill walls (MI) can be frequently found as interior and exterior partitions for architectural purposes in RC structures. Although they are generally considered to be nonstructural elements, their influence on the seismic performance of the framed structures is significant. A common practice in the modern and old RC buildings is to use the ground-storey of the buildings for commercial; garages, storages, shops...etc. In the present work, the effect of the MI walls on seismic performance of the RC framed structures has been studied. For that, 2-D, sixstorey, three-bay, framed structures, which are fully and partially infilled with the MI walls, have been studied using different infill walls' configuration in order to simulate the cases of ignoring or taking the stiffness and strength of the IM walls, and simulating the common practice of removing the infill walls in the ground storey. Double-strut nonlinear cyclic model for masonry walls has been utilized in order to account for the structural action of the MI walls. Dynamic time history analysis using three different ground motions records to represent wide range of frequency contents, has been used to perform the seismic analysis of the considered model configurations. Some selected numerical simulation results in terms of base shear forces, lateral deflections, and inter-storey drift ratios are obtained for all the considered configurations and presented in a comparative way.
\end{abstract}

Keywords- Infilled frames, Open ground storey, Soft storey, Time history analysis, Base shear, Storey Drift.

\section{Introduction}

MI walls are commonly used in RC structures as interior and exterior partition walls. Common practice has always been to ignore infill during the design and the analysis of the reinforced concrete framed structures due to its highly nonlinear nature which is difficult to be simulated.

The interaction between $\mathrm{RC}$ framed structures and infill walls was investigated and large numbers of experimental and analytical researches were conducted on this topic.

Mohamed Magdy Abdelaziz

Faculty of Engineering / Fayoum University Egypt

Mohamed Sayed Gomaa

Faculty of Engineering / Fayoum University

Egypt

Hany EL-Ghazaly

Faculty of Engineering / Fayoum University

Egypt
The first published experimental research on infilled RC frames subjected to racking load was by Polyakov [1] who performed a number of large scale tests in order to determine the racking strength of infilled frames. A significant number of studies showed experimentally and analytically (Holmes [2], Asteris [3], and Milheiro et al. [4]) that the presence of the infill walls increases the stiffness and the strength of the framed building.

Because of the common use of the masonry infilled frames throughout the world, many lessons can be learned by studying their damage patterns after the occurrence of earthquakes. The infill walls may have a negative impact on the integrity of some building. The common practice of using the ground-floor of the buildings as an open storey for commercial purposes leads to vertical stiffness irregularities and may cause soft storey mechanism as shown in Fig. 1.

\section{Infilled Frames Modeling}

Several methods have been developed to model the infill walls. They may be classified into two groups, micro-models and macro-models. Micro-models focus on detailed behavior of each individual infill panel (i.e., stiffness, capacity ...etc.) while the macro-models study the overall structural system response. The main advantage of the macro-models is its computational simplicity as it is based on equivalent strut model as firstly described by Polyakov [5] who suggested replacing the infill wall by a diagonal compression strut.

In this work, the masonry infill walls have been modeled through the simplified macro-model proposed by Crisafulli [6], which considered two pairs of compression-tension diagonal struts to carry axial loads across two opposite diagonal corners and two pairs of shear struts with a shear spring to carry the shear from the top to the bottom of the panel as illustrated in Fig. 2. The implementation of the double-strut nonlinear cyclic model for IM walls was firstly carried out by Smyrou et al. [7].

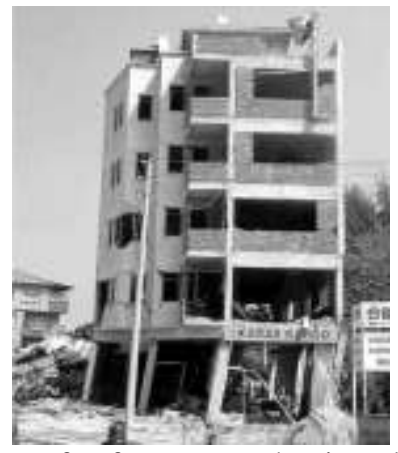

Fig. 1 Formulation of soft story mechanism during Turkey earthquake, 1999 (Sezen [8]) 

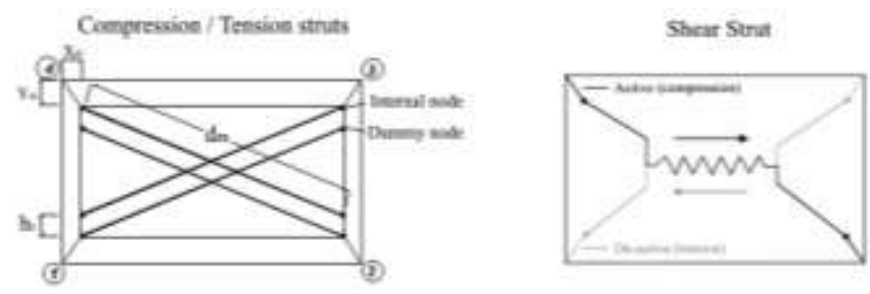

Fig. 2 Infill masonry walls proposed model by Crisafulli [6] (For simplicity, only struts in one direction are shown)

\section{Modeling Verification}

In order to be certain that the modeling successfully predicts the approximate real behavior of the structure, an experimental test by Pinto et al. [9] has been modeled. Geometry details of the tested frame are shown in Fig. 3. Further information on the tested frame can be found in Pinto et al. [9].

The frame has been modeled in SeismoStruct software [10]. Inelastic displacement-based frame elements divided in 200 fibers have been used for modeling beams and columns. Each structural member has been subdivided into inelastic beam-column elements with smaller length at the member ends so as to ensure the accurate modeling of expected plastic hinge zones. The frame has been tested under an artificial record which is plotted in Fig. 4.

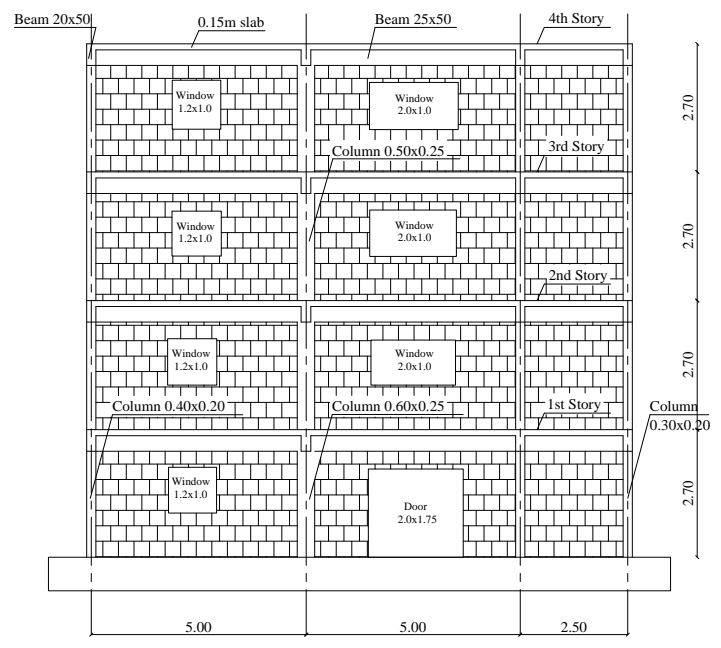

Fig. 3 Elevation view of the tested frame

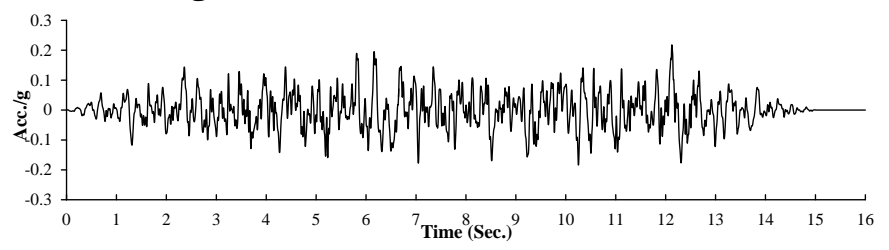

Fig. 4 Ground motion acceleration time histories for 475-yrp

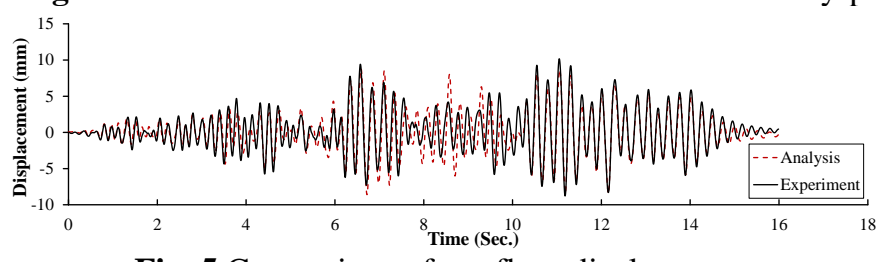

Fig. 5 Comparison of top floor displacement

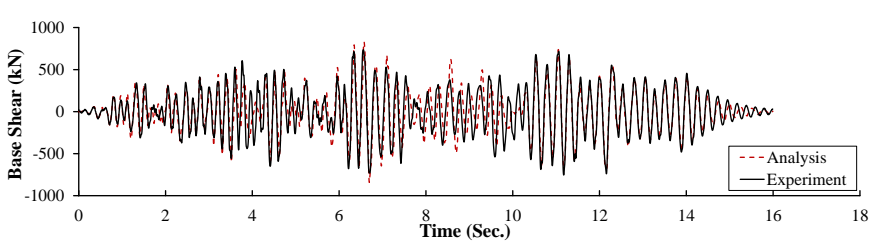

Fig. 6 Comparison of base shear

Fig. 5 and Fig. 6 provide the time histories (experimental and numerical results) of storey displacements and storey shear for the frame. A first overall observation is that the analytical results demonstrate a good match with those of the experimental results. Small differences are identified. However, this is still within an acceptable range. The numerical model of the infilled frame manages to describe the frequency content and reach the peak value in most cycles. Undoubtedly, the model succeeded in predicting the behavior of the infilled frame with acceptable accuracy.

\section{Parametric Study}

In order to investigate the seismic performance of the framed buildings infilled with MI walls, as well as, framed buildings with open soft stories, 2-D, six-storey, three-bay, framed structures, which are fully and partially infilled with the MI walls, have been studied using different infill walls' configuration (e.g. bare frame $[\mathrm{BF}]$ case in which no infill walls have been utilized at all floors, infilled frame [IF] case in which the infill walls have been located in all stories in all bays, and open ground storey [OGS] case in which the infill walls have been located in all floors except in the ground story) as shown in Fig. 7. The frames are RC framed structures with three bays of $5.0 \mathrm{~m}$ span composed of moment resisting frames (no shear walls have been utilized) spaced at $5.0 \mathrm{~m}$ with a constant floor height of $3.0 \mathrm{~m}$. All beams have the same dimensions $(0.25 \mathrm{~m}$ width $\mathrm{x} 0.60 \mathrm{~m}$ depth) in all floors as shown in Fig. 8. For all investigated models, slabs have been taken to be $0.15 \mathrm{~m}$ in thickness. The columns cross sections and reinforcements are shown in Fig. 9 for the frame.

The design has been carried out according to the Egyptian regulations [11]. Only the gravity loads have been considered in the design of these frames. Vertical distributed loads on beams and concentrated loads on the columns have been considered in order to simulate the self-weight of the frame, the live load, the finishings, other self-loads and certainly the infill walls. For the infill walls, a specific weight of $14 \mathrm{kN} / \mathrm{m}^{3}$ is considered in the calculations.

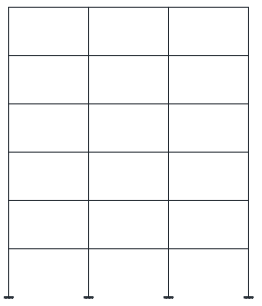

(a)

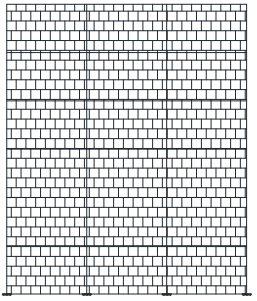

(b)

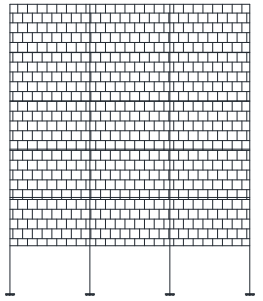

(c)
Fig. 7 Different studied models
(a) $\mathrm{BF}$
(b) IF
(c) OGS 
Proc. of the Seventh International Conference On Advances in Civil and Structural Engineering - CSE 2017.

Copyright ( $)$ Institute of Research Engineers and Doctors. All rights reserved.

ISBN: 978-1-63248-127-6 doi: 10.15224/ 978-1-63248-127-6-05

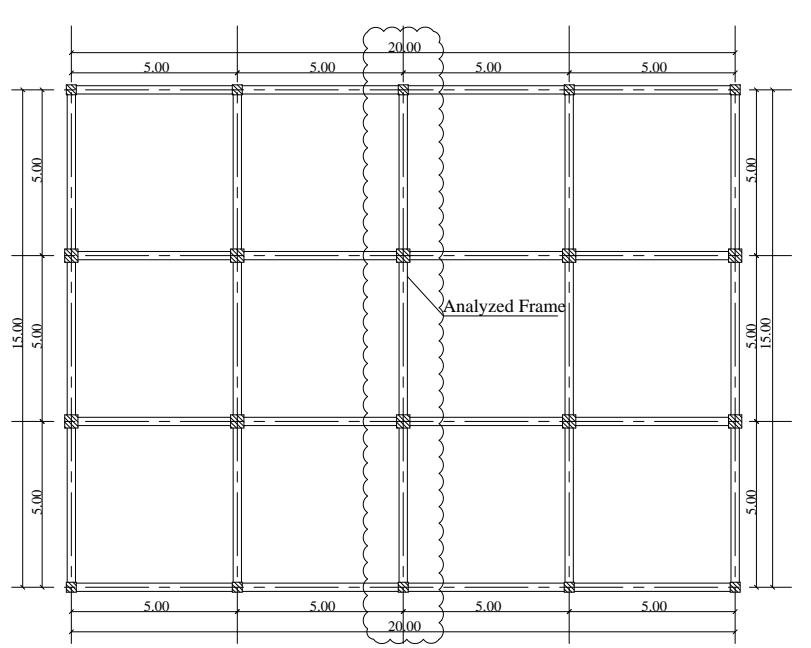

Fig. 8 Plan of Regular RC frame buildings
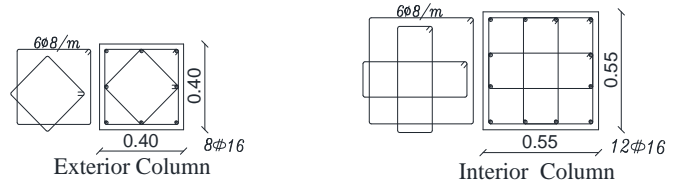

Fig. 9 Column reinforcement details

\section{Material Properties}

The materials have been chosen to have properties close to those used in Egypt. The concrete used corresponds to a normal weight with cubic compressive strength of $25 \mathrm{MPa}$. The reinforcing steel used is high grade steel of class $36 / 52$ according to the Egyptian standard with nominal values of yield strength, ultimate strength, and ultimate strain equal to $360 \mathrm{MPa}, 520 \mathrm{MPa}$ and $12 \%$; respectively.

Nonlinear concrete model proposed by Mander et al. [12] has been employed for defining the concrete material while the Menegotto-Pinto steel model proposed by Menegotto and Pinto [13] has been employed for defining the reinforcing steel material as presented in table 1, table 2 and Fig. 10.

The non-load bearing infill walls of hollow bricks have been assumed to be used in the modeling with dimensions $0.12 \times 0.25 \times 0.06 \mathrm{~m}$. Plaster of $15 \mathrm{~mm}$ has been applied on both sides of the wall. Material properties adopted for masonry infill walls are presented in table 3 . The width (w) of the infill diagonal strut is computed using the expression by Paulay and Preistley [16]; given in Equation 1.

$$
\mathrm{w}=0.25 \mathrm{~d}_{\text {inf }}
$$

where $\mathrm{d}_{\text {inf }}=$ the diagonal length of infill.

Table 1 The characteristic parameters for concrete model

\begin{tabular}{|c|c|}
\hline Mean compressive strength $\left(\mathrm{f}_{\mathrm{C}}\right)$ & $20.8 \mathrm{MPa}$ \\
\hline Mean tensile strength $\left(\mathrm{f}_{\mathrm{t}}\right)$ & $2 \mathrm{MPa}$ \\
\hline Modulus of elasticity $\left(\mathrm{E}_{\mathrm{c}}\right)$ & $2.14 \mathrm{E}+004 \mathrm{MPa}$ \\
\hline
\end{tabular}

. Table 2 The characteristic parameters for reinforcing steel model

\begin{tabular}{|c|c|}
\hline Modulus of elasticity $\left(\mathrm{E}_{\mathrm{S}}\right)$ & $2.00 \mathrm{E}+005 \mathrm{MP}_{\mathrm{a}}$ \\
\hline Yield strength $\left(\mathrm{f}_{\mathrm{y}}\right)$ & $360 \mathrm{MPa}$ \\
\hline Strain hardening parameter $(\mu)$ & 0.00677 \\
\hline
\end{tabular}

Table 3 Material properties adopted for brick infill walls numerical modeling

\begin{tabular}{|l|l|}
\hline Compressive strength & $5 \mathrm{MP}_{\mathrm{a}}$ \\
\hline Young's modulus & $5000 \mathrm{MP}_{\mathrm{a}}$ \\
\hline Tensile strength & $0.575 \mathrm{MP}_{\mathrm{a}}$ \\
\hline Wall thickness with plaster & $0.15 \mathrm{~m}$ \\
\hline Strut diagonal width & $1.25 \mathrm{~m}$ \\
\hline
\end{tabular}

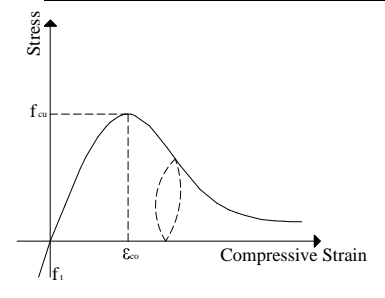

(a)

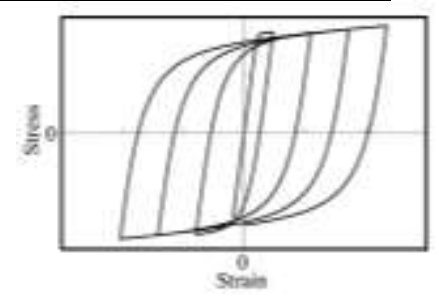

(b)
Fig. 10 Stress - strain relationships for (a) concrete, (b) reinforcing steel

\section{Numerical Modeling}

The frames have been modeled in SeismoStruct software [14]. Inelastic displacement-based frame elements divided in 200 fibers have been used for modeling beams and columns. Beams and columns have been modeled as extending from the center of one beam-column joint to the center of the next. Each structural member has been subdivided into inelastic four beam-column elements with smaller length at the member ends so as to ensure the accurate modeling of expected plastic hinge zones. The effective width of slab has been taken to be $0.95 \mathrm{~m}$ for each span according to the Egyptian code provisions. In order to represent the strong foundation, fixed supports have been used for the ground columns. The rest of the nodes have been restrained in the out-of-plane degree of freedoms in order to perform two-dimensional analysis.

\section{Dynamic Time History Analysis}

In dynamic analysis, the nonlinear inelastic response of a structure subjected to earthquake loading can be predicted over time during and after the application of the load. The seismic action may be introduced by means of acceleration loading curves at the supports, which may also be different at each support so as to represent asynchronous ground excitation.

In this study, three sets of ground motion (Fig. 11) have been used to represent wide range of frequency content (e.g. High Frequency Content [HFC], Medium Frequency Content [MFC], and Low Frequency Content [LFC]). The basis used to classify ground motions according to their frequency content is introduced in Equation 2 by Kwon, and Elnashai [15]. The selected ground motion records have been scaled to Peak Ground Acceleration (PGA) of 0.2g.

$$
\begin{gathered}
\text { LFC }: \mathrm{a} / \mathrm{v}<0.8 \mathrm{~g} / \mathrm{m} \mathrm{s}^{-1} \\
\text { MFC }: 0.8 \mathrm{~g} / \mathrm{m} \mathrm{s}^{-1} \leq \mathrm{a} / \mathrm{v} \leq 1.2 \mathrm{~g} / \mathrm{m} \mathrm{s}^{-1} \\
\text { HFC }: 1.2 \mathrm{~g} / \mathrm{m} \mathrm{s}^{-1}<\mathrm{a} / \mathrm{v} .
\end{gathered}
$$




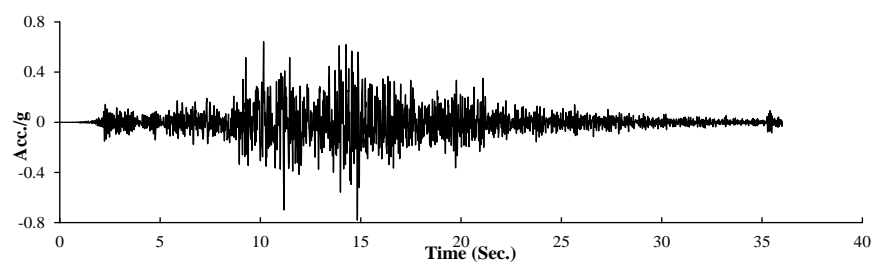

(a)

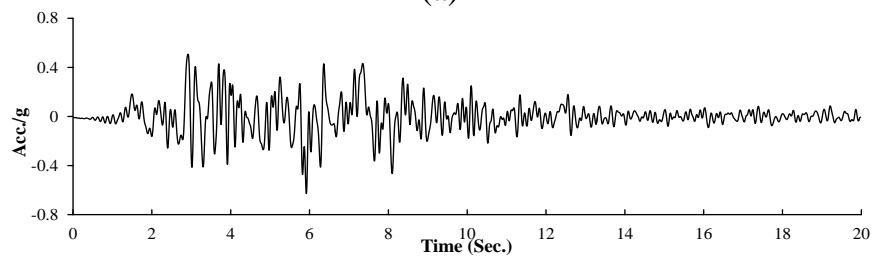

(b)

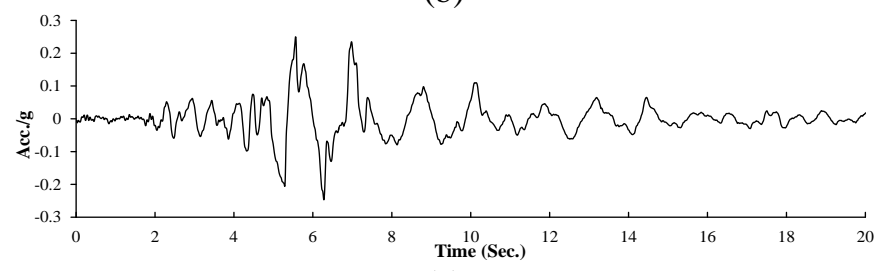

(c)

Fig. 11 Ground motion accelerations
(a) HFC
(b) MFC
(b) LFC

\section{Numerical Results and Discussion}

\section{A. Modal Analysis}

A modal analysis has been undertaken in order to provide an initial prudence into the structures. For the three configurations of the buildings, significant changes in the fundamental periods of the first three modes have been detected. As shown in table 4, the period of the first mode for the $\mathrm{BF}$ has decreased to around $68.2 \%$ and 47.6 for the IF and OGS; respectively. This can be due to the fact that the presence of the infill panels makes the structure have higher stiffness than the BF building model.

Table 4 Natural periods for the structures

\begin{tabular}{|c|c|c|c|}
\cline { 2 - 4 } \multicolumn{1}{c|}{} & $1^{\text {st }}$ Mode & $2^{\text {nd }}$ Mode & $3^{\text {rd }}$ Mode \\
\cline { 2 - 4 } \multicolumn{1}{c|}{} & $\mathrm{T}_{1}(\mathrm{sec})$ & $\mathrm{T}_{2}(\mathrm{sec})$ & $\mathrm{T}_{3}(\mathrm{sec})$ \\
\hline BF & 0.867 & 0.283 & 0.163 \\
\hline IF & 0.276 & 0.104 & 0.099 \\
\hline OGS & 0.454 & 0.128 & 0.099 \\
\hline
\end{tabular}

\section{B. Time History Analysis Results}

Roof displacement time histories of the BF, IF, and OGS under wide range of frequency content (HFC, MFC, and LFC) with PGA of $0.2 \mathrm{~g}$ are presented in Fig. 12. It can be seen that the displacements decrease with the presence of the MI walls in the frame. The maximum roof displacement is associated with the BF as compared to the IF and OGS. This can be due to the fact that the IF, and OGS have higher stiffness than the BF building model under the applied dynamic lateral load. The displacement of the BF can be reduced by 72 to $90 \%$ after using infill walls in the whole height. Despite the existence of the soft storey in the OGS their displacement is less than the BF displacement by about 67 to $83 \%$.

In Fig. 13, the time histories of the base shear are presented for ground motions with HFC, MFC, and LFC; respectively. The plotted curves clearly show a significant difference between the cases of IF and BF in which modeling of MI is ignored. The presence of the infill walls increases the base shear. It can be seen that the maximum base shear is associated with the IF. It can also be noticed that the presence of the infill walls in the BF magnifies the maximum base shear values by about 2.5 to 3.1 , and 1.4 to 1.9 , for the IF, and OGS, respectively. Therefore, the columns in the ground storeys in OGS are more vulnerable as the shear forces acting on columns are considerably higher than those associated with the BF.

Fig. 14 demonstrates the differences among the maximum inter-storey drift ratio profiles of the IF, OGS, and BF under ground motions with HFC, MFC, and LFC; respectively. It is noted that the drift profiles from the dynamic analysis represent the envelopes of peak drift ratios beyond the near collapse state, not actual profiles at a given instant of time. These obtained plots illustrate the differences among the drift ratio profiles of the building structure modeled as BF, IF, and OGS. It can be seen that the maximum value of inter-storey drift ratios for the $\mathrm{BF}$ occurs around the middle stories. However, the maximum drift ratios for the OGS have sudden increase at the ground storey resulting in a soft storey mechanism. It can also be noted that the maximum drift ratio for the IF occurred at the ground level. This is probably due to the early cracking of the infill walls at the ground storey. The infilled frames have less inter-storey drift at all floors than the bare ones.

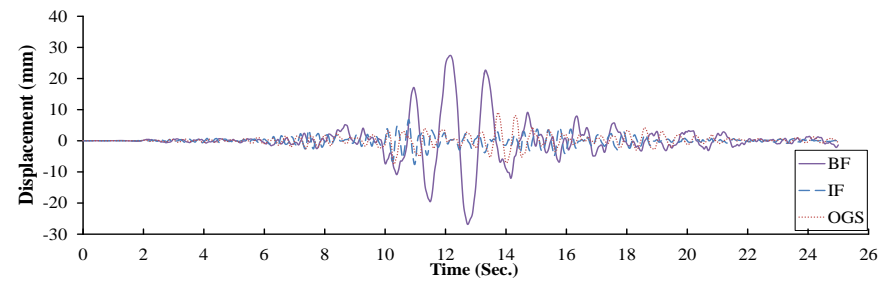

(a)

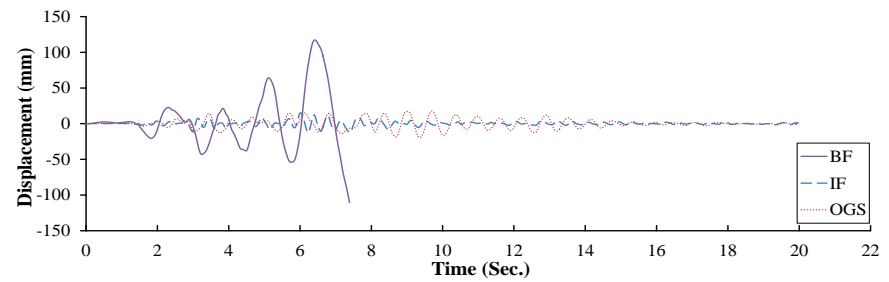

(b)

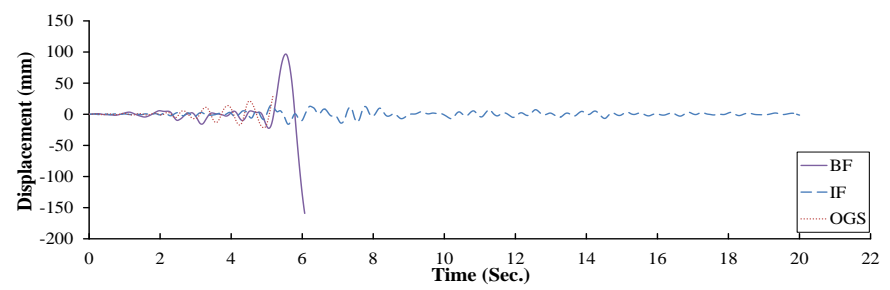

(c)

Fig. 12 Displacement response at roof for each building under
(a) HFC
(b) MFC
(c) LFC 


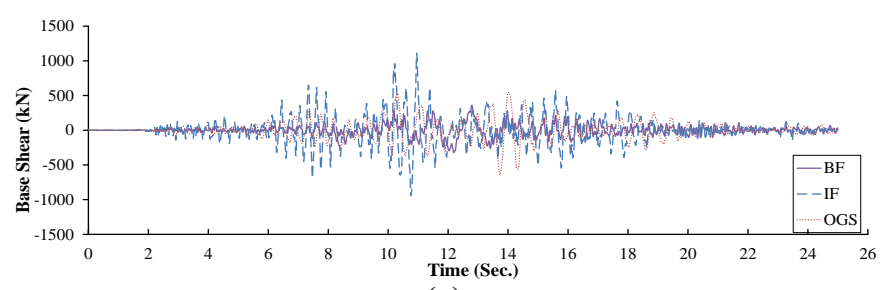

(a)

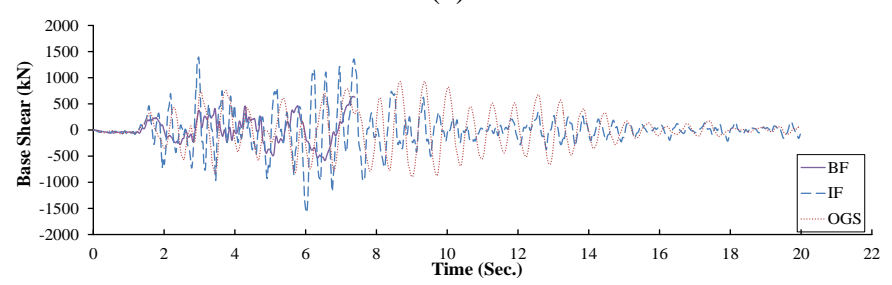

(b)

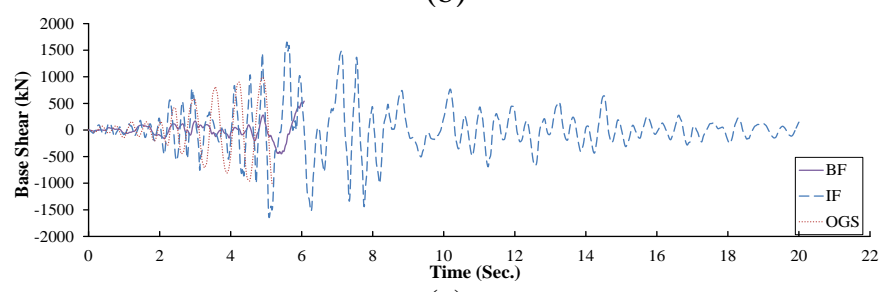

(c)

Fig. 13 Base shear for each building under

(a) HFC

(b) MFC

(c) LFC

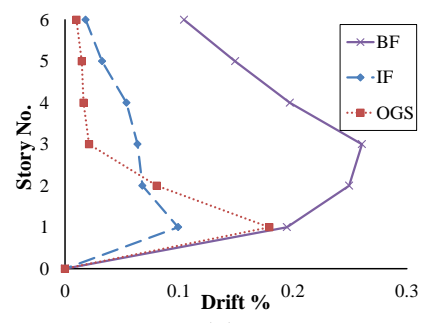

(a)

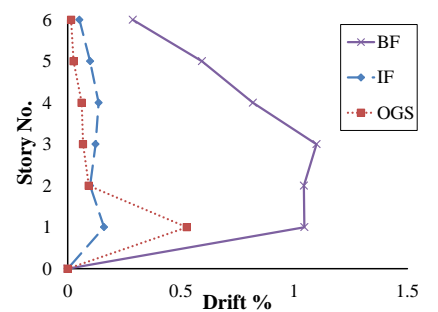

(b)

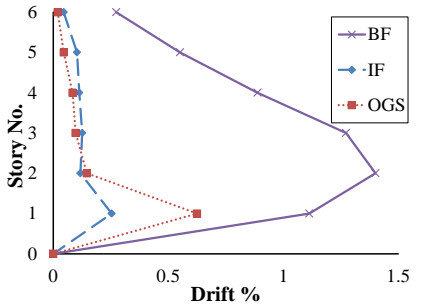

(c)

Fig. 14 Maximum inter-story drift ratio profiles under (a) HFC

(b) MFC

(c) LFC

\section{Conclusion}

This current work aims to study the performance of RC framed structures which are fully or partially infilled with MI walls under seismic loading. In order to attain this goal, a numerical study of 2-D, six-storey, three-bays, RC framed structures has been conducted using time history analysis. For those cases, the following conclusions may be drawn:

- The MI walls strongly influence the global performance of the framed structures as the performance of the BF does significantly vary from the other various infill walls' configuration under lateral loading.
- The regular distribution of the MI walls can significantly improve the seismic performance of $\mathrm{RC}$ framed structures during earthquakes in terms of lateral capacity, storey drifts and displacement control despite the fact that failure of infill occurs in the early stages of the earthquake. Their presence makes the frames able to deform for a longer period without collapse. Furthermore, taking their interaction into consideration leads to reduce the storey displacements and increase the lateral capacity as compared to the BF case.

- The existence of soft storey in the ground level due to omitting the infill walls makes the columns in this storey more vulnerable as the shear forces acting on columns are considerably higher than those associated with the BF.

- The national building codes should consider the soft storey irregularity due to omitting the infill walls.

\section{References}

[1] Polyakov, S. V. (1956). "Masonry in framed buildings." Published by: Gosudarstvennoe izdatel'stvo Literatury postroitel'stvu i arkhitekture. Translated from the Russian by G.L. Cairns.

[2] Holmes, M. (1963). "Combined loading on infilled frames." Proceedings of the Institution of Civil Engineers, 25(1), 31-38.

[3] Asteris, P. G. (2003). "Lateral stiffness of brick masonry infilled plane frames.” Journal of Structural Engineering, 129(8), 1071-1079.

[4] Milheiro, J., Rodrigues, H., \& Arêde, A. (2016). "Evaluation of the contribution of masonry infill panels on the seismic behaviour of two existing reinforced concrete buildings." KSCE Journal of Civil Engineering, 20(4), 1365-1374.

[5] Polyakov, S. V. (1960). "On the interaction between masonry filler walls and enclosing frame when loaded in the plane of the wall." Translations in earthquake engineering, 2(3), 36-42.

[6] Crisafulli, F. J. (1997). "Seismic behaviour of reinforced concrete structures with masonry infills." PhD Thesis, University of Canterbury, New Zealand.

[7] Smyrou, E., Blandon, C., Antoniou, S., Pinho, R., \& Crowley, H. (2006). "Implementation and verification of a masonry panel model for nonlinear pseudo-dynamic analysis of infilled RC frames." Proceedings of the first European conference on earthquake engineering and seismology, 355, Geneva, Switzerland

[8] Sezen, H., Whittaker, A. S., Elwood, K. J., \& Mosalam, K. M. (2003). "Performance of reinforced concrete buildings during the August 17, 1999 Kocaeli, Turkey earthquake, and seismic design and construction practise in Turkey." Engineering Structures, 25(1), 103-114.

[9] Pinto, A., Verzeletti, G., Molina, J., Varum, H., Pinho, R., \& Coelho, E. (2002). "Pseudo-dynamic tests on non-seismic resisting RC frames (bare and selective retrofit frames)." EUR Report, 20244.

[10] SeismoStruct V.7. "A computer program for static and dynamic nonlinear analysis of framed structures." http://www. seismosoft. com.

[11] ECP-203. (2007). "Egyptian code for design and construction of reinforced concrete structures. Housing and Building National Research Center, Ministry of Housing." Utilities and Urban Planning, Cairo.

[12] Mander, J. B., Priestley, M. J., \& Park, R. (1988). "Theoretical stressstrain model for confined concrete." Journal of structural engineering, 114(8), 1804-1826.

[13] Menegotto, M. \&Pinto P. E. (1973). "Method of analysis for cyclically loaded RC plane frames including changes in geometry and non-elastic behavior of elements under combined normal force and bending." In Proc. IABSE symposium on resistance and ultimate deformability of structures acted on by well-defined repeated loads (pp. 15-22).

[14] Paulay, T., \& Priestley, M. N. (1992). "Seismic design of reinforced concrete and masonry buildings." John Wiley \& Sons Inc., New York.

[15] Kwon, O. S., \& Elnashai, A. (2006). "The effect of material and ground motion uncertainty on the seismic vulnerability curves of RC structure." Engineering structures, 28(2), 289-303. 